\title{
Two New Cases of True Hermaphroditism
}

\author{
E. BARREIRO, A. PERALTA, J. MONEREO, J. A. USANDIZAGA, F. CONTRERAS, \\ and A. SWARTZ
}

\section{From Clinica Infantil 'La Paz' de la Seguridad Social, Madrid, Spain}

Conventionally, an individual who has both ovarian and testicular tissue is described as a true hermaphrodite. The phenotypic appearances may be those of either sex, and the internal and external genitalia may range from those of a normal female to those of a normal male. Relatively few cases have been fully studied, and it is only recently that it has been possible to supplement clinical and laparotomy findings with cytogenetic studies. Only in about 50 of the 200 reported cases has the karyotype been established. Most of these patients have been reared as males and the diagnosis is seldom made before puberty. Some of these 'males' have presented after puberty with cyclic vaginal bleeding, haematuria, or gynaecomastia, presumably due to oestrogen production by ovarian tissue. The gonads are usually in the abdomen but sometimes present as a testis or an ovotestis in an inguinal hernia. Merrill and Ramsey (1963) reviewed 114 cases of true hermaphroditism and distinguished three gonadal situations: (i) cases having a testis on one side and an ovary on the other; (ii) cases with an ovotestis on one side and a testis or ovary on the other; and (iii) where either there is a testis and an ovary on both sides, or an ovotestis on each side.

At laparotomy most cases are found to have a uterus, but where there is gonadal asymmetry the differentiation of the genital ducts usually corresponds closely to the nature of the adjacent gonad (Guinet, 1965). In those subjects having a predominantly male phenotype some degree of hypospadias, with or without cryptorchidism, is common and if a gonad presents in an inguinal hernia it is usually a testis or an ovotestis. Gonads with ovarian tissue rarely present outside of the abdomen.

It is generally agreed that the majority of true hermaphrodites are chromatin positive, and have XX sex chromosomes. From the literature it appears that some $65 \%$ of true hermaphrodites have

Received May 27, 1969.
XX chromosomes; about $5 \%$ have XY chromosomes, and the remainder are mosaic in respect of sex chromosomes. For example, 45,X/46,XY (Hirschhorn, Decker, and Cooper, 1960), 45,X/46,XY (Conen et al., 1961), 46,XX/47,XXY (Turpin, Lejeune, and Breton, 1962), 46,XX/47,XXX (Ferguson-Smith, Johnston, and Weinberg, 1960; Botella Llusia, 1960), 46,XX/48,XXYY (Blank et al., 1964), 46,XX/46,XY/47,XXY (Ribas-Mundó and Prats, 1965), and 46,XY/47,XXY/49,XXYYY (Fraccaro et al., 1962). Two true hermaphrodites in young children have recently been seen in the Clinica Infantil.

\section{Case Reports}

Case 1. This child presented as a boy aged $4 \frac{1}{2}$ whe had been born after a normal pregnancy and deliveryo the birthweight was $3600 \mathrm{~g}$. The rest of the sibs were probably normal but it was not possible to get an adequate family history as they were in the Canary Islands. At birth he was cyanosed, but recovered completely in about an hour. He appeared well nourished and apparently normal in development except for the genitalia. There were two small skin folds like labia, and at the upper end of the cleft between them there was a small structure like a penis, but without a urinary meatus. At its base there was a small blind ending opening, and $5 \mathrm{~mm}$. posteriorly a second opening from which urine was passed. Catheterization of this opening revealed that it split into two channels and cystoscopic examination failed to reveal a bladder. These structures appear to represent a urogenital sinus. Laparotomy revealed a hypoplastic uterus and Fallopian tubes and on each side there was small round white gonad about $1 \mathrm{~cm}$. in diameter. The left gonad was removed and histology revealed it to be an ovotestis (Fig.).

Cells from buccal smears did not have sex chromatin, and chromosomal analysis from peripheral blood showed a single cell line with $\mathbf{4 6}$ chromosomes, the sex chromosomes being XY. In all 50 cells analysed it was not possible to culture any solid tissue. The histological appearances are shown in the Fig.

Case 2. This child was seen when 3 months old. The pregnancy and delivery were normal and the birth weight was $2900 \mathrm{~g}$. There was one older normal male 


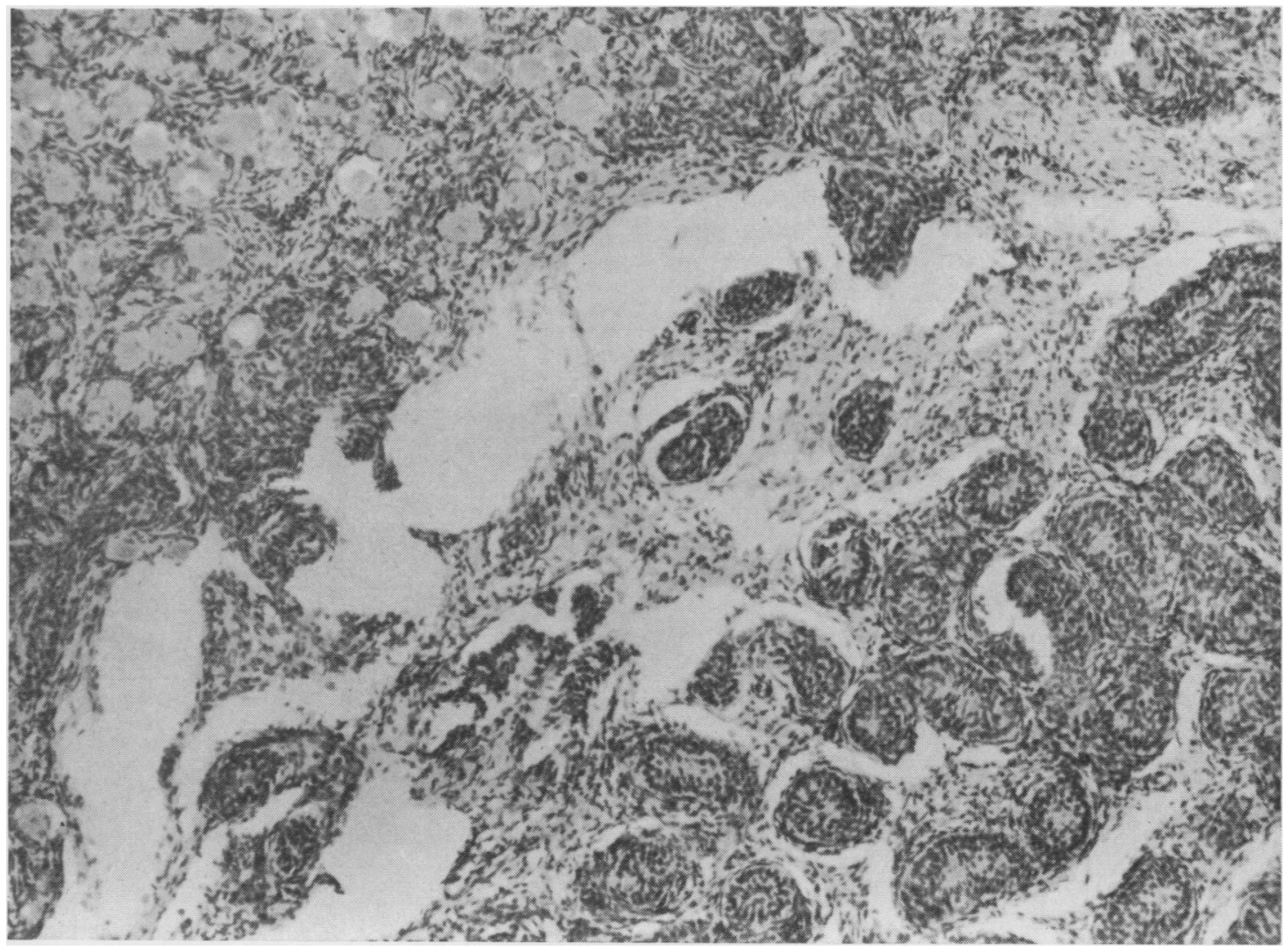

FIG. The upper part of the photograph, representing the cortex on the surface of the gonad, shows typical ovarian stroma with ill-developed follicles. There is a sharp transition to the lower part of the section which shows degenerative testicular tubules.

sib. The child appeared to be normally developed except for anomalous genitalia. There were skin folds like labia (that on the right being the more prominent), which had a rugose scrotum-like appearance. A round mass about $1 \mathrm{~cm}$. in diameter was palpable within this right fold. Between the skin folds was an orifice like a urogenital sinus with a urinary meatus leading from it. From the upper part of the orifice there was a mid-line raphe leading towards a small penis. On rectal examination a small mass about $2 \mathrm{~cm}$. in length was palpable in the position of a uterus. Radiography after intravenous injection of urographin showed no abnormalities of kidneys, ureters, or bladder. Cystoscopic examination appeared to show a normal female urethra and bladder. The vagina appeared to be normal. At laparotomy a gonad with the appearance of a small testis was found in the right labial fold. There was a left hemi-uterus with Fallopian tube and a gonad in the broad ligament. Biopsy of the right gonad showed it to be a testis and the left, which was removed, proved to be an ovotestis.

The buccal smears showed a sex chromatin in $12 \%$ of the cells. Chromosomal analysis from blood leucocytes showed three cell lines which were interpreted as having
$\mathrm{XX}, \mathrm{XY}$, and $\mathrm{XXY}$ sex chromosomes. Of 50 cells analysed, 24 were $47, \mathrm{XXY}, 15$ were $46, \mathrm{XY}$, and 11 were $46, X X$. Unfortunately it was not possible to culture skin or other tissues.

\section{Discussion}

The finding that in most true hermaphrodites it is only possible to show an $\mathrm{XX}$ sex chromosome cell line is difficult to reconcile with the evidence from other sources, which suggests that a Y chromosome is needed to induce differentiation of a testis from undifferentiated gonads. Several explanations have been advanced: the simplest is that there is an XY cell line which has not been identified and could even be confined to the testicular tissue itself. Ferguson-Smith (1966) suggests that the apparent $\mathrm{XX}$ sex chromosome pair represents one normal $\mathrm{X}$ and one having an interchange of material with a Y chromosome. Only about $5 \%$ of true hermaphrodites are reported as having XY sex chromosomes as in Case 1 . 
The 46,XX/46,XY/47,XXY mosaicism in Case 2 cannot be explained in terms of irregular distribution of chromosomes at a single cell division. It is explicable in various ways which need not be elaborated here. The zygote could have been XY, or XXY. Ribas-Mundó and Prats (1965) reported a case of true hermaphroditism which was very similar clinically to ours and had the same karyotype. Burgio, Severi, and Biscatti (1966) reported an apparently male child who had a uterus with the same mosaic karyotype. He had a testis on one side and no gonad on the other. They classified the case as mixed gonadal dysgenesis.

True hermaphroditism in sibs has been reported on several occasions (Rosenberg, Clayton, and Hsu, 1963; Overzier, 1963), but in all these familial cases where the chromosomes have been examined both affected subjects have had XX chromosomes.

\section{Summary}

Two cases of true hermaphroditism diagnosed at $4 \frac{1}{2}$ years and 3 months of age are reported. Both patients had been regarded as males. One child had $\mathrm{XY}$ sex chromosomes. The other was a $46, \mathrm{XX} /$ $46, \mathrm{XY} / 47, \mathrm{XXY}$ mosaic. Both had ovotestes.

\section{REFERENCES}

Blank, C. E., Zachary, R. B., Bishop, A. M., Emery, J. L., Dewhurst, C. J., and Bond, J. H. (1964). Chromosome mosaicism in a hermaphrodite. Brit. med. F., $2,90$.

Botella Llusia, J. (1960). Sobre un nuevo caso de hermafroditismo verdadero. (Variedad bilateral con doble ovoteste en el canal inguinal.) An. Acad. nac. (Madr.), 77, 261.

Burgio, G. R., Severi, F., and Biscatti, G. (1966). Dysgénésie gonadique mixte à caryotype $\mathrm{XY} / \mathrm{XX} / \mathrm{XXY}$. Pédiatrie, 21, 687 .

Conen, P. E., Bailey, J. D., Allemang, W. H., Thompson, D. W., and Ezrin, C. (1961). A probable partial deletion of the Y chromosome in an intersex patient. Lancet, $2,294$.

Ferguson-Smith, M. A. (1966). X-Y chromosomal interchange in the aetiology of true hermaphroditism and of XX Klienefelter's syndrome. ibid., 2, 475.

, Johnston, A. W., and Weinberg, A. N. (1960). The chromosome complement in true hermaphroditism. ibid., 2, 126.

Fraccaro, M., Taylor, A. I., Bodian, M., and Newns, G. H. (1962). A human intersex ('True hermaphrodite') with XX/XXY/XXYYY sex chromosomes. Cytogenetics, 1, 104.

Guinet, P. (1965). Les problèmes posés par l'hermaphrodisme vrai. Minerva pediat., 17, 611.

Hirschhorn, K., Decker, W. H., and Cooper, H. L. (1960). Human intersex with chromosome mosaicism of type XY/XO. Report of a case. New Engl. F. Med., 263, 1044.

Merrill, J. A., and Ramsey, J. E. (1963). True hermaphroditism. Obstet. and Gynec., 22, 505.

Overzier, C. (1963). (Editor.) True hermaphroditism. In Intersexuality. Academic Press, New York.

Ribas-Mundó, M., and Prats, J. (1965). Hermaphrodite with mosaic XX/XY/XXY. Lancet, $2,494$.

Rosenberg, H. S., Clayton, G. W., and Hsu, T. C. (1963). Familial true hermaphrodism. F. clin. Endocr., 23, 203.

Turpin, R., Lejeune, J., and Breton, A. (1962). Génétiquehermaphrodisme XX/XXY. C.R. Acad. Sci. (Paris), 255, 3088. 